\title{
TOURISM CARRYING CAPACITY FOR BEACHES IN TULUM NATIONAL PARK, MEXICO
}

\author{
MARÍA DENY D POOT QUINTAL \& ROMANO G. SEGRADO PAVÓN \\ Universidad de Quintana Roo, Mexico
}

\begin{abstract}
The tourist use of natural spaces causes multiple, simultaneous, short and long term impacts on the environment, which is why it is necessary to establish limits of use, as in other social activities. The objective of the study was to establish the tourism carrying capacity of two beaches of Tulum National Park (TNP), which have ample tourist and recreational visitation. The multi-criteria method was carried out with a SWOT, satellite images, and interviews with key informants. As a result, it was determined that the maximum limit was 976 simultaneous users for the two most visited beaches of the TNP, Santa $\mathrm{Fe}$ and Pescadores, with four use zones with different densities. The public institutions will be able to design better strategies for the conservation of natural spaces and achieve greater satisfaction of the users of these natural spaces.
\end{abstract}

Keywords: tourism, carrying capacity, beaches, Tulum.

\section{INTRODUCTION}

The promotion of tourism is mainly based on the attractiveness of its natural resources and landscapes, built in sensitive ecosystems, which consequently can influence degradation processes in reefs, mangroves, forests, beaches, and any pristine site. In this sense, unplanned, chronic, intensive and extensive tourist visitation negatively affects natural spaces, such as the beaches of the Tulum National Park (TNP).

At the international level, tourist visitation to national parks has become a mercantilized process, which under the premise of economic and social benefits, facilitates the use of the landscape as a commodity that creates spaces of social segregation, disarticulated and differentiated in goods and services, which increases levels of population marginalization and promotes forms of consumption of the territory that only favor those who have more [1]. In addition, national parks face increasing pressure to use contiguous zones of influence for the construction and development of residential areas [2]. TCC studies on tourist beaches are limited and almost exclusively based on social perception criteria, omitting zoning and ecological factors.

The commercialization of natural spaces, by criteria of landscape, recreation, social trends, among others, has evolved in such a way that it exerts chronic negative impacts on the natural environment in natural spaces. In the case of Tulum National Park, the tourist activity promoted under the slogan of nature contemplation has generated a series of problems such as the increase in hotel infrastructure, perception of overcrowding among visitors, changes in sea turtle behavior, affecting coastal dunes, as well as multiple situations of illegal use of the territory.

Tulum National Park received 1,773,929 visitors in 2016 [3], who visited the archaeological zone inside the Park and adjacent to the beach area, where 18 hotels, cabins or villas are also present, representing 420 rooms [1]. In this same space, the fishing and tourism cooperatives carry out activities, which are carried out by the inhabitants. Other spaces are also found, integrated by restaurants, beach clubs and other companies of tourist services of support. The immediate zone of influence located to the south of the Park, with a strip of approximately $7 \mathrm{~km}$ of coastline; it is complemented with fishing activities; small 
hotels prevail. Along this coastal strip there are 46 hotels with 546 rooms, as well as houses conditioned for lodging service [1].

The TNP constitutes the only terrestrial Natural Protected Area (NPA) in the main tourist corridor of Cancun - Tulum (Riviera Maya). The main tourist attraction is the archaeological zone of Tulum and the nearby beaches: Santa Fe, Pescadores, Maya. While the archeological zone has access control and regulations for visitation, on the beaches there is no registration or access control for visitors and environmental regulations are minimal or non-existent. This situation promotes several situations that negatively impact the TNP.

Establishing the Tourism Carrying Capacity (TCC) for the conservation of natural spaces with visitation is a complex problem because the boundaries are multidimensional, contiguous, non-linear, polygens and heterogeneous, which perform various functions of rights, territorialization and regulation in social and ecological communities. In the case of National Parks, limits are a regulatory strategy observed in the form of norms, rules and principles, created to regulate, prevent and control interactions between tourists and their environment, establishing a standard for social behavior in a given area, in the ecological environment and social dimensions [4].

The World Tourism Organization [5] argues that in order to avoid or mitigate negative impacts it is necessary to establish the carrying capacity, to determine the maximum use that can be made of a natural space without damaging its resources, to decrease the levels of satisfaction of tourists or to generate negative impacts on society, the local economy or culture. With this foundation and in order to operationalize the paradigm of sustainable development and maintain the ecological capacities of resilience, resistance and recreation, the following research question was proposed: what is the tourism carrying capacity of the beaches of Tulum National Park? Developing tourism management strategies helps to avoid translimitation, mitigate negative effects and achieve socio-ecological stability of natural spaces.

\section{THEORETICAL FRAMEWORK}

The fundamental social conduct consists of not harming the interests of others, either by express legal provision or tacit understanding, and assuming part of the work and sacrifices to be made to protect the social interest. On this basis, when a person or some social group affects the interests of others, society can judge the rights constituted over a territory and the question of imposing or interfering with the limits to the general welfare is open to discussion in Mill [6].

According to Ostrom and Merino [7] society must create and enforce social norms, because there is a retribution, besides being indispensable for social continuity, through stable institutions that establish understandable limits, clear norms and supervision, for the sustainable use of natural resources. This argument, contrary to the one put forward by Hardin [8] in his classic "Tragedy of the commons", establishes that an organized social group can achieve a measured use of natural resources, considering balanced social and individual proportions.

The creation of social norms and limits seek to achieve a balance between the social and individual benefit of nature, by means of sanctions, laws, norms and other forms of behavior regulations, within certain ranges of acceptability, to stimulate cooperation and strategies that lead to communal welfare through the maintenance of the ecosystem [7].

Boundaries present themselves in multiple forms and can be influenced by administrative, social, ecological, cultural, even historical reasons [9], [10]. In human intervention on nature, adaptive management involves the determination of "adaptive limits", which is defined as "the point at which an actor's objectives cannot be assured of intolerable risks through 
adaptation actions" [9], therefore, the limit was reached and there is no certainty of maintaining the ecosystem service in its outstanding conditions [10].

In the case of tourism, it involves limiting the access of tourists to certain natural areas, for reasons of public interest, either by strict or flexible rules, such as tourism carrying capacity and limits of acceptable change, management techniques and planning, In natural areas, zoning, limits of acceptable change and tourism carrying capacity, are applied to estimate the limits of resistance and resilience for fauna and flora with public use.

In the state of the knowledge, diverse authors have analyzed the tourism carrying capacity and the limits of acceptable change, with different methods. The analysis of the scientific literature revealed that the main paradigm applied was sustainable development [11]-[13].

As a research method, the elaboration of thematic maps for tourist routes and dispersion as a way of diversifying the tourist space and its use has a broad development with territorial emphasis [11], [12], [14]. On the other hand, from social analysis, visitor satisfaction and the perception of overcrowding have been the most prominent factors in studies with surveys and indicators [15]-[17]. In general, it can be stated that the trend in the TCC and LAC studies is multidisciplinary, for a better understanding and application of the variables [13].

In relation to the problems tackled, five relevant aspects stand out: (1) lack of consideration of natural limitations [11], [13], [16]; (2) visitors' influence on the affectation of nature [11]-[14]; (3) concentration of tourist activities [12], [15]; (4) economic relevance of tourist activity [18]; and (5) visitor perception and satisfaction level [11], [15]-[17], [19].

Among the main variables identified are the level of overcrowding [11], [15]; level of satisfaction [17], [19] and number of visitors [12]-[14], [16], [18]. Territory or physical space is the common factor in virtually all studies.

In general, the models for TCC and LAC determination reflect porosity and interaction in determining limits that are considered adequate, either by ecological or social criteria, as a theoretical contribution to sustainability. However, because variables of primary interest cannot be measured directly, data on restrictive factors are used and aspects of community governance must be properly developed to promote conservation.

\section{METHOD}

Tulum National Park is located in Quintana Roo, in the municipality of Tulum, has an area of 664 hectares, which are distributed mainly along the coastal area, almost in parallel with federal highway 307. It is the only NPA between Cancun and Tulum and is located around the archaeological zone of Tulum [20]. Inside the Park there are three public beaches: Santa Fe, Pescadores and Playa Maya. The first two were selected for this research, due to their wide visitation, both by tourists and the local population. The extension of both beaches is approximately $630 \mathrm{~m}$ and the crystalline waters with a turquoise blue color, as well as the fine sand, soft and white color, with palms.

The descriptive method was applied, because territorial data were measured, collected and evaluated, as well as determining the number of people that can support the study area without suffering permanent or short-term damage to its natural environment. Because this study is subject to natural seasons such as summer and winter, it is considered to be transversal.

The focus of this research is quantitative, because for the achievement of the objectives, a serie of field observations are carried out that measure the space covered by the two public beaches inside the Park, in Santa Fe and Pescadores; which allows a numerical analysis. The study was based on the method established by Cifuentes Arias et al. [21] which is widely documented and available on the Internet, so no further descriptions are presented in this 
regard. This method was complemented with Betancourt and Herrera-Moreno [22], who established a zoning by uses of the coastal region (beach area).

The territory is the basis of the analysis for the physical carrying capacity, after which a zoning by uses of the coastal region of study is carried out. Betancourt and Herrera-Moreno [22] affirm that the subdivision of the beach zone (Fig. 1) into areas allows its management through the assignment of occupation criteria, use and functional relations between the zones that conform it to achieve an optimal use of the beach resource based on a great variety of criteria that are observed in Table 1.

In Fig. 2, the zones established within the area of the beaches to be studied.

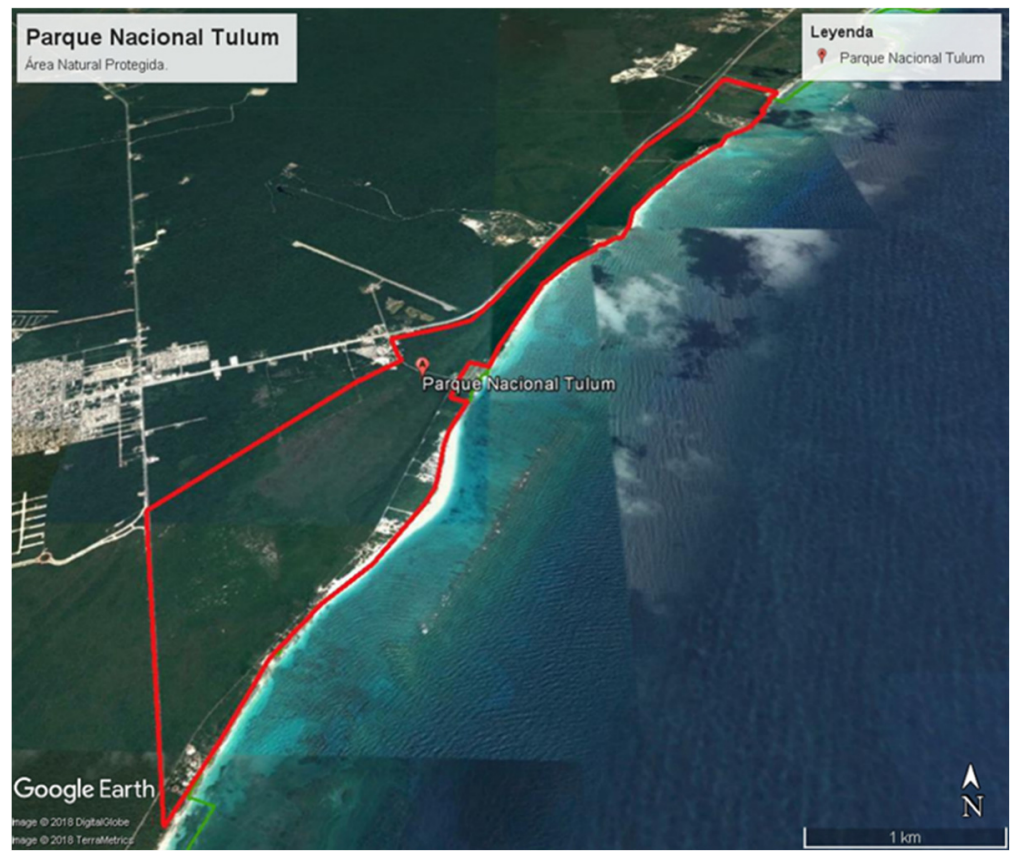

Figure 1: Limits of Tulum National Park. (Source: own elaboration based on Google Earth, 2018.)

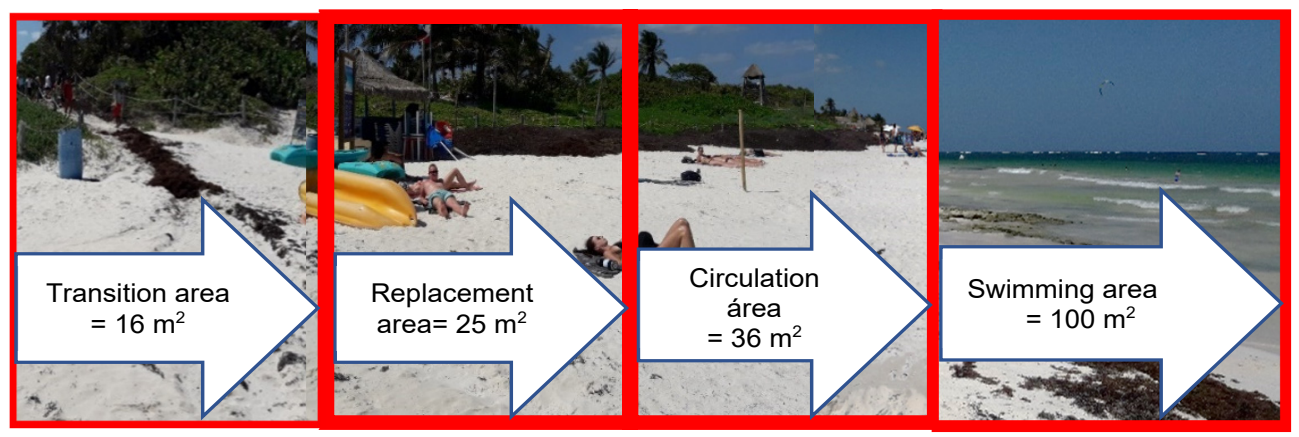

Figure 2: Zoning of the beach. (Source: Betancourt and Herrera-Moreno [22].) 
Table 1: Table Zoning criteria by uses of the coastal zone. (Source: Betancourt and Herrera-Moreno [22].)

\begin{tabular}{|c|c|c|}
\hline Zone & Characteristics & Activities \\
\hline $\begin{array}{l}\text { Swimming } \\
\text { area }\end{array}$ & $\begin{array}{l}\text { Area where the visitors, alone or in } \\
\text { groups, are located in a quiet way. It is } \\
\text { an area of } 100 \mathrm{~m}^{2} \text { per user for a depth } \\
\text { of less than } 1.6 \mathrm{~m} .\end{array}$ & $\begin{array}{l}\text { Visitors can sit or stand for a } \\
\text { bath or chat. }\end{array}$ \\
\hline $\begin{array}{l}\text { Intensive use } \\
\text { or circulation }\end{array}$ & $\begin{array}{l}\text { Strip of beach where the tides } \\
\text { intervene, and that are in constant } \\
\text { contact with the sea and that possesses } \\
\text { firmness to the step. Its width depends } \\
\text { on the slope of the beach and the } \\
\text { amplitude of the tide. It is an area of } 36 \\
\mathrm{~m}^{2} \text { per user. }\end{array}$ & $\begin{array}{l}\text { In and out of the swimmers, } \\
\text { walks among the foam of the } \\
\text { waves and where different } \\
\text { types of games are } \\
\text { practiced. }\end{array}$ \\
\hline $\begin{array}{l}\text { Resting or sun } \\
\text { exposure }\end{array}$ & $\begin{array}{l}\text { A strip of sand above the high tide } \\
\text { limit, where the geomorphological } \\
\text { characteristics of the beach vary. Its } \\
\text { length and width determine the } \\
\text { maximum physical carrying capacity } \\
\text { of the beach. It is an area of } 25 \mathrm{~m}^{2} \text { per } \\
\text { user. }\end{array}$ & $\begin{array}{l}\text { The users rest and sunbathe } \\
\text { taking advantage of the } \\
\text { existing vegetation or using } \\
\text { installed infrastructures and } \\
\text { recreational, sports or rest } \\
\text { activities are carried out that } \\
\text { do not need permanent } \\
\text { facilities. }\end{array}$ \\
\hline $\begin{array}{l}\text { Transition to } \\
\text { the beach }\end{array}$ & $\begin{array}{l}\text { Strip far from the coastline, behind the } \\
\text { resting area. Its transverse extension } \\
\text { varies from the area of solar exposure. } \\
\text { It is an area of } 16 \mathrm{~m}^{2} \text { per user. }\end{array}$ & $\begin{array}{l}\text { Entry, exit and search for a } \\
\text { space in the beach area, play } \\
\text { and rest activities are carried } \\
\text { out, in the sun or in the } \\
\text { shade, and service centers } \\
\text { can be installed. The } \\
\text { activities are carried out } \\
\text { informally, although } \\
\text { support facilities can be } \\
\text { found. }\end{array}$ \\
\hline
\end{tabular}

According to Betancourt and Herrera-Moreno [22] the areas where users sunbathe and bathe are not excluded, but are part of the same physical unit and therefore must be intertwined with each other, so that it does not happen that visitors who enjoy the sun do not find space within the bathing area or vice versa.

The eqn to determine the Physical Capacity in each zone of the beach is the following: PCC (Number of users in the beach area) = Surface area of the area $\left(\mathrm{m}^{2}\right) /$ Occupancy criterion ( $\left.\mathrm{m}^{2} / \mathrm{user}\right)$.

For the calculation of this area, the modified occupancy criterion established by Mexican Standard NMX-AA-120-SCFI-2016 [23] was adopted, which defines the beach as a geomorphological unit formed by the accumulation of unconsolidated sediments of different types and whose limits are established in lower and upper limits. Once the PCC has been established and the areas of use on the beach have been determined, the actual carrying capacity of the study site can be evaluated. 
The measurement of correction factors, or "critical limiting factors" is of great importance for the calculation of the actual Carrying Capacity. The correction factors according to Segrado and Arroyo [24] are certain restrictions or limitations to the CC directly linked to some aspect of the tourist attraction, be it physical, ecological, management, safety, visitor satisfaction.

The natural correction factors identified for this research were the following elements: sea turtle nesting seasons; yellow or red flags; algae and red tides; sargasso, because it diminishes the enjoyment space for visitors. It is worth mentioning that these factors are subject to annual temporality and are not permanent. On the other hand, the identified social factors presented very subjective characteristics, so all were discarded, with the exception of the minimum personal space for the enjoyment of the beach, in which a certain consensus was achieved.

With respect to the management capacity, the restrictive aspects, but not limiting, were the capacity for emergency attention (personnel and schedule); sanitary (optimal density), water treatment; freshwater showers; awning service; educational induction program; program for monitoring environmental variables and administration program, palm shelters and changing rooms.

\section{RESULTS}

The physical carrying capacity was determined by the available surface area, the area occupied by one person and the number of times the site can be visited by the same person in one day. In this regard, it was considered appropriate to select the minimum distance of $16 \mathrm{~m}^{2}$ per person, a daily schedule of attention to visitors in the study area was carried out from 7 a.m. to 7 p.m. making a total of 12 hours of attention, likewise it was determined that the average time of visit is 8 hours. With the substitution of the previous data, NV $=12$ hours day $/ 8$ hours average visit $=1.5$ visit per day per visitor.

Once the data were collected, the substitution of values was applied to determine the Physical Carrying Capacity (PCC): $\mathrm{PCC}=82,269.207 \mathrm{~m}^{2}$ x 1.5 probable visit per day / 16 $\mathrm{m}^{2}$ per person $=7,712$ people per day. However, this preliminary figure must be analyzed considering the zoning of the study area according to their respective measures (see Table 2).

The division of the beach in areas with different types of uses, allows its arrangement by establishing occupation criteria and functional relations between the areas that structure it to achieve optimal use of the beach resource. To this end, four zones were established. Therefore, by applying the zoning criteria, and then adding them together, the PCC of the beach is obtained. The eqn for zoning is as follows: Area $\left(\mathrm{m}^{2}\right) /$ Occupancy criterion $\left(\mathrm{m}^{2} /\right.$ user $)=$ Number of users in the beach area.

The data considered in the zone of "transition to the beach" were replaced, with a total of $30,299.117 \mathrm{~m}^{2}$ and a criterion of $16 \mathrm{~m}^{2}$ per person, the eqn was applied and obtained as a result: 1,893 people. Similarly, the data considered in the area of "rest or sun exposure", with a total of $13,134.773 \mathrm{~m}^{2}$ and a criterion of $25 \mathrm{~m}^{2}$ per person, the eqn was applied and obtained as a result: 525 people. The data considered in the area of "intensive use or circulation" were substituted, with a total of $13,340.376 \mathrm{~m}^{2}$ and a criterion of $36 \mathrm{~m}^{2}$ per person, and the result was: 370 people. Finally, the eqn was applied with the data considered in the area of "swimming area", with a total of $25,494.941 \mathrm{~m}^{2}$ and a criterion of $81 \mathrm{~m}^{2}$ per person, obtaining as a result: 314 people. Adding the subtotals for each area $(1,893$ people +525 people +370 people +314 people) gives the PCC: 3,102 people. Table 3 summarizes the zoning results.

In order to obtain the Real Carrying Capacity (RCC), it was necessary to establish the natural and social Correction Factors (CF). Among the former were nesting seasons (turtles), flags, algae, red tide, and serge; among the latter were garbage bins, tables, chairs, beds, umbrellas, palapas, lifeguard tower, and boats. To calculate the total area of enjoyment space, 
the total available area of $82,269.21 \mathrm{~m}^{2}-4,754.48 \mathrm{~m}^{2}$ of the total area limiting the correction factors was considered, resulting in $77,514.73 \mathrm{~m}^{2}$ of enjoyment space, which represents $5.78 \%$ of the total available area of the zones.

The beaches are subject to seasonal and interannual variations of natural processes such as the case of the identified natural correction factors: flags, algae, red tide and sargasso. These natural phenomena begin spontaneously and in an unpredictable way, and have a variable duration, although in some sectors they occur with a certain periodicity and in others occasionally; it happens mainly in summer seasons although in the last four years its periodicity has increased, with the consequence that the beaches of these states are temporarily closed, which is why it is an important factor to be considered in this study, as it prevents immersion in water, even in areas close to the beach. From the correction factor "waves", during seasons of strong winds there is a change in the frequency and strength of tides, generating that the access to the sea is limited or better known as bathing area. As a preventive measure, visitors are warned by the use of flags: red (danger), yellow (precaution) and green (free use).

Once the factors are determined, the values are substituted to determine the actual carrying capacity $(\mathrm{RCC})$, whose eqn is $\mathrm{RCC}=[(\mathrm{PCC} \times(100 \%-\mathrm{CF})]$. So the $\mathrm{RCC}=((3,042$ people per day $\times(100 \%-5.78 \%))=(3,102 \times 94.22 \%)=2,922$ people per day. Thus, the actual Carrying Capacity of the area is 2,922 people per day for the study area.

In the study area, which includes the public beaches of Santa Fe and Pescadores, there are restaurant services; bathrooms (private), lifeguard tower, showers (private), hotel, beach club (includes hotels and cabins that call themselves beach clubs, due to the extension of the beach on which they have a concession).

Table 2: Study area zoning. (Source: Based on Qgis 3 and Google Earth Pro, 2019.)

\begin{tabular}{|l|l|}
\hline Zoning & Area in $\mathbf{~ m}^{\mathbf{2}}$ \\
\hline Transition area & $30,299.117$ \\
\hline Rest area or sun exposure & $13,134.773$ \\
\hline Area of intensive use or circulation & $13,340.376$ \\
\hline Swimming area & $25,494.941$ \\
\hline Total & $82,269.207$ \\
\hline
\end{tabular}

Table 3: Beach zoning (Source: Prepared by the authors, 2019.)

\begin{tabular}{|l|c|c|}
\hline Zoning & Criteria & Total people \\
\hline Transition area & $16 \mathrm{~m}^{2}$ per person & 1,893 \\
\hline Rest area or sun exposure & $25 \mathrm{~m}^{2}$ per person & 525 \\
\hline Area of intensive use or circulation & $36 \mathrm{~m}^{2}$ per person & 370 \\
\hline Swimming area & $81 \mathrm{~m}^{2}$ per person & 314 \\
\hline Total & & 3,102 \\
\hline
\end{tabular}


It was also considered the optimal infrastructure for the administration to offer a quality service for visitors and of which the beaches that were part of the research do not count: parking, dressing rooms, viewpoint, access for people with disabilities, palm shelters (to protect from the rays of the sun), kiosks for rent of umbrellas, chairs and tables, among other factors. The percentage value, as a comparison between the real and the ideal, was $29.95 \%$.

The equipment used to carry out the activities of the personnel working in the study area includes the working tools available to the lifeguards: first aid kit, rescue buoys, torpedoes, whistles, radios, ATVs; while the police present buggy, armament and radio vehicles. The percentage value of the comparison of the ideal equipment against the real one is $50.35 \%$.

People hired to support or provide services to visitors collaborate with the quality of visitation. In the public beaches of Santa $\mathrm{Fe}$ and Pescadores there are two guards, two police officers and two park rangers; although due to the increase in the recharge of serge, the need for cleaners was identified for this affectation. The percentage value of the real towards the ideal reached $12.50 \%$.

The administration of the public beaches of Santa Fe and Pescadores has not established any type of cultural or educational activities, although occasionally garbage collection and turtle release days are held, known as environmental education activities. The percentage value for the qualitative value between the ideal and the real reaches $41.67 \%$.

To obtain the total value for the Administration category, the average of all the resulting factors is obtained and the eqn is applied. Substituting: Adm. $=29.95 \%+50.35 \%+12.50 \%$ $+41.67 \% \times 100 / 4=33.62 \%$. Therefore, the management capacity of the administration is below that established for the achievement of adequate enjoyment of the recreational site by visitors.

With regard to food, the total capacity is 312 chairs and food production allows to feed this number of people every 60 minutes, so the Food indicator is equal to $100 \%$. There are only two private bathrooms in the study area, specifically on the public beach of Santa Fe, but there are no data on septic tanks, so the value of $0 \%$ was assigned to this criterion.

In the public beaches of Santa Fe and Pescadores there are a total of 12 bins for the deposit of garbage in general, without indicating the type of waste or residue that can be deposited in them. There is no program or containers for the separation of solid waste or waste recovery, therefore the value for this criterion is $0 \%$.

Once the values of the indicators that make up the Management Capacity (MC) were obtained, the eqn was applied: $33.62 \%+100 \%+0 \%+0 \% \times 100 / 4=33.40 \%$. Therefore, the management of activities and achievement of objectives and goals of the administration of the public beaches Santa Fe and Pescadores, have limitations that affect the RCC.

The Effective Carrying Capacity (ECC) is the maximum limit of visits that can be allowed, based on the resources of the local administration to order and manage them. The eqn $\mathrm{CCE}=2,922 \times 33.40 / 100$ was applied, resulting in 976 daily visitors to the public beaches of Santa Fe and Pescadores. This figure is the maximum daily number of people who can make use of the tourist site under the current conditions analyzed.

\section{DISCUSSION}

It is a complex process to establish the number of visitors that an area can support without being affected, because there is a lack of consideration of natural limitations and concentration of tourist activities in a small number of places, giving greater relevance to economic development that encourages tourism than to conservation and protection of the protected natural area. The variety of parameters to be considered when determining the carrying capacity is another of the difficulties that must be faced in carrying out the research; 
among which are: type of activity, seasonality, schedule, conservation status of the natural area's resources, existing facilities and installations, degree of user satisfaction, and so on.

The studies by Lobo et al. [18]; Collins-Kreiner et al. [11]; Malik and Bhat [12] and Lobo [14] are those that agree with this research since the purpose is to establish the carrying capacity as a method to be applied to determine the spatial correlation and distribution of the tourist space; based on an analysis and the establishment of an adequate tourist planning of the natural areas that allow the diversification of the tourist activity in Tulum National Park. However, studies by Rathnayake [15]; Giglio et al. [16] and Zhang et al. [17] helped to complement the carrying capacity in a multidisciplinary manner to have a better understanding and adaptability of the variables [13]. However, aspects such as satisfaction levels and visitor perception were discarded, since for this research determining the level of satisfaction or perception was not one of the established objectives.

Betancourt and Herrera-Moreno [22] zoned beaches with three criteria, which are: intensive use or circulation, rest or solar exposure and solar transition. However, for this research it was considered pertinent to add the bathing area, because it is a real factor of the physical capacity of the beach, since at some point during their stay, the visitor may be inside the sea, expanding the space and therefore increasing the FCC.

The main finding is that there is a disproportionate increase in visitor service infrastructure in the area and its area of influence, in contrast to its management capacity of the administration, which remarked to $33 \%$. What is surprising is that there is not a management plan, despite being a protected natural area with the designation of National Park, whose priority should be the protection of its natural resources, the increase of its flora and fauna, and in general, the preservation of ecosystems and their elements [25]. It was also identified that natural correction factors such as sargasso are currently limiting the carrying capacity of the study area, despite the fact that social factors play a relevant role.

\section{CONCLUSION}

This research determined the tourism carrying capacity of Tulum National Park, specifically in its primary zone of influence, which includes the public beaches of Santa $\mathrm{Fe}$ and Pescadores. The result is 976 visitors as the maximum limit of visits that can be made to the site during each day.

In order to carry out this research, three specific objectives were proposed; among which is the establishment of indicators for Tourism and Recreational Carrying Capacity. For this reason, the study area was zoned in four zones, which are: transition area, rest or solar exposure, intensive use or circulation and bathing area, from which the correction factors were determined both natural and social of each. Therefore, in the transition area, garbage cans, tables, chairs, beds, umbrellas, palm shelters, and lifeguard tower were identified as limiting areas; likewise, the nests of turtles and motorboats were identified as limiting areas for resting; likewise, in the bathing area, only motorboats were identified as limiting areas; as for the area of intensive use, limitations were not identified due to the fact that it is imperative to leave it free for visitors to move from one area to another.

Another specific objective was to determine the natural and social factors that determine the Tourism Carrying Capacity of Tulum National Park. As for the social correction factor identified within the park, there are garbage cans, tables, chairs, beds, umbrellas, palm shelters, lifeguard towers, and boats since these elements occupy spaces that limit visitors' areas of enjoyment. The natural correction factors were the nesting season, flags, sargasso, algae and red tide; since they reflect a limitation of enjoyment space and also limits the activities that tourists can develop, it is worth mentioning that everything described above is subject to annual temporality and does not occur all year round. 
Determining the Tourism Carrying Capacity of the public beaches of Santa Fe and Pescadores will help establish limits on tourism development in the area, which in turn will contribute to better planning and tourism management by managers based on the carrying capacity of the ecosystems, thus facilitating decision making and the design of strategies to manage the tourist use of the TNP. Because the research contributes concretely to Tulum National Park as a prevention tool that contribute to better tourism development, achieving true sustainability of the study area allowing a better distribution of economic benefits among communities and sectors involved.

\section{ACKNOWLEDGEMENTS}

Special thanks to the National Council of Science and Technology (CONACYT), to the University of Quintana Roo, Cozumel Unit; for the support, the means and facilities granted to obtain the degree and development of this research work.

\section{REFERENCES}

[1] Arroyo, L., Segrado, R. \& López, Á., Estructura hotelera como modificadora del espacio litoral en Tulum, México, 2019. www.redalyc.org/articulo.oa?id $=456144904007$. Accessed on: 12 Nov. 2019 .

[2] Arnberger, A. \& Brandenburg, C., Past on-site experience, crowding perceptions, and use displacement of visitor groups to a peri-urban national park. Environmental Management, 40(1), pp. 34-45, 2007.

[3] SEDETUR Indicadores Turísticos Enero - Diciembre 2016. Quintana Roo 2017. http://sedetur.qroo.gob.mx/estadisticas/indicadores/2017/Indicadores\%20Tur\%20\%20Enero\%20-\%20Diciembre\%202016.pdf. Accessed on: 6 Nov. 2017.

[4] Segrado, P.R. \& Chuc Piña, I., Sustainable tourism development in Parque Nacional Lagunas de Montebello, México. WIT Transactions on Ecology and the Environment, vol. 8, pp. 83-93, 2018.

www.witpress.com/Secure/elibrary/papers/ST18/ST18009FU1.pdf

[5] Indicadores de desarrollo sostenible para los destinos turísticos, Madrid, España: WTO elibrary, 2005. www.ucipfg.com/Repositorio/MGTS/MGTS14/MGTSV-07/ tema2/OMTIndicadores_de_desarrollo_de_turismo_sostenible_para_los_destinos_ turisticos.pdf. Accessed on: 25 Feb. $20 \overline{19}$.

[6] Mill, J., On Liberty, Longman, Roberts \& Green: London, 1869.

[7] Ostrom, E. \& Merino, S.L., El gobierno de los bienes comunes, México: Fondo de Cultura Económica, 2011.

[8] Hardin, G., The Tragedy of the Commons The population problem has no technical solution; it requires a fundamental extension in morality, Science, 1968. https://science.sciencemag.org/content/sci/162/3859/1243.full.pdf. Accessed on: 18 Feb. 2019.

[9] Dow, K., Berkhout, F., Preston, B.L. \& Klein, R.J.T., Limits to adaptation. Nature Climate Change, 3(4), pp. 305-7, 2013.

[10] Klein, H.J., Cooper, J.T., Molloy, J.C. \& Swanson, J.A., The Assessment of commitment: Advantages of a unidimensional, target-free approach. Journal of Applied Psychology, 99(2), pp. 222-238, 2014.

[11] Collins-Kreiner, N., Malkinson, D., Labinger, Z. \& Shtainvarz, R., Are birders good for birds? Bird conservation through tourism management in the Hula Valley, Israel. Tourism Management, 38, pp. 31-42, 2013.

[12] Malik, M.I. \& Bhat, M.S., Sustainability of tourism development in Kashmir - Is paradise lost? Tourism Management Perspectives, 16, pp. 11-21, 2015. 
[13] Maia, T. \& Smith, C., Scenario-based planning for tourism development using system dynamic. Tourism Management, 68, pp. 336-354, 2018.

[14] Lobo, H.A.S., Tourist carrying capacity of Santana cave (PETAR-SP, Brazil): A new method based on a critical atmospheric parameter. Tourism Management Perspectives, 16, pp. 67-75, 2015.

[15] Rathnayake, R.M., How does 'crowding' affect visitor satisfaction at the Horton Plains National Park in Sri Lanka? Tourism Management Perspectives, 16, pp. 129-138, 2015.

[16] Giglio, V.J., Luiz, O.J. \& Schiavetti, A., Marine life preferences and perceptions among recreational divers in Brazilian coral reefs. Tourism Management, 51, pp. 49$57,2015$.

[17] Zhang, Y., Li, X.R. \& Su, Q., Does spatial layout matter to theme park tourism carrying capacity? Tourism Management, 61, pp. 82-95, 2017.

[18] Lobo, H.A.S. et al., Projection of tourist scenarios onto fragility maps: Framework for determination of provisional tourist carrying capacity in a Brazilian show cave. Tourism Management, 35, pp. 234-243, 2013.

[19] Zhang, Y., Li, X.R., Su, Q. \& Hu, X., Exploring a theme park's tourism carrying capacity: A demand-side analysis. Tourism Management, 59, pp. 564-578, 2017.

[20] Tulum a la Vanguardia. Parque Nacional Tulum. Una muralla abierta a la conservación, 2007. www.conanp.gob.mx/conanp/dominios/tulum/. Accessed on: 8 Nov. 2017.

[21] Cifuentes Arias, M. et al., Capacidad de Carga Turística de las Áreas de Uso Público del Monumento Nacional Guayabo, Costa Rica. WWW Centroamérica, 1999. http://awsassets.panda.org/downloads/wwfca_guayabo.pdf. Accessed on: 23 Nov. 2017.

[22] Betancourt, F.L. \& Herrera-Moreno, A., Acercamiento de la Capacidad de Carga Física de Playa Grande, Cayo Levantado, Samaná, República Dominicana. Programa EcoMar República Dominicana, 2005. https://programaecomar.webs.com/ CayoLevantado.pdf. Accessed on: 23 Nov. 2017.

[23] Norma Mexicana NMX-AA- 120-SCFI-2016: Que Establece los Requisitos y Especificaciones de Sustentabilidad de Calidad de Playas. Norma Mexicana, 2016. www.gob.mx/cms/uploads/attachment/file/213866/NMX-AA-120-SCFI-2016.pdf. Accessed on: 19 Mar. 2019.

[24] Segrado, P.R. \& Arroyo, L., El Método de la Capacidad de Carga Turística Aplicado a la Medición de la Sustentabilidad de Cozumel, México. TURyDES, 2(5), pp. 1-10, 2009. Available from: http://www.eumed.net/rev/turydes/05/sa.htm. Accessed on: 23 Nov. 2017.

[25] Ley General del Equilibrio Ecológico y la Protección al Ambiente. Cámara de Diputados del H. Congreso de la Unión, 2018. www.diputados.gob.mx/LeyesBiblio/ pdf/148_050618.pdf. Accessed on: 10 Apr. 2018. 